\title{
The value of blood gas analysis in predicting the outcome of cardiopulmonary resuscitation among in-of-hospital cardiac arrest patients
}

\section{Kan gazı analizinin hastane içi kardiyak arrestlerde kardiyopulmoner resüsitasyonun sonucunu belirlemedeki değerliliği}

\author{
Adnan Yamanoğlu
}

Department of Emergency Medicine, Katip Celebi University, Ataturk Training and Research Hospital, Izmir, TURKEY

Corresponding author: Adnan Yamanoğlu, MD, Department of Emergency Medicine, Katip Celebi University, Ataturk Training and Research Hospital, Izmir , Turkey

E-mail: adnanyaman29@gmail.com

Received/Accepted: May 21, 2020 /August 21, 2020

Conflict of interest: There is not a conflict of interest.

\section{SUMMARY}

Objective: The aim of this study was to determine the value of blood gas parameters in predicting return of spontaneous circulation (ROSC) in patients developing in-of-hospital cardiopulmonary arrest (CPA).

Method: Adult patients developing in-of-hospital cardiac arrest, and with blood gas analysis obtained on the first $10 \mathrm{~min}$ of cardiopulmonary resuscitation (CPR) were included in the study. Patients were divided into two groups based on CPR outcomes, ROSC and non-ROSC. The ability of blood gas parameters to differentiate these two groups was then subjected to statistical analysis. Receiver Operating Characteristic (ROC) curve was drawn for those parameters that emerged as significant between the two groups, and the ability of the parameters to distinguish the two groups was determined. Regression analysis was performed to determine the value of blood gas parameters in predicting the outcome of CPR. All statistical analyses were performed a 95\% confidence interval, and $\mathrm{p}<0.05$ was considered statistically significant.

Results: Sixty-seven patients were included in the study, 14 of whom achieved ROSC, while ROSC was not achieved in the other 53. The ability of $\mathrm{pH}, \mathrm{HCO}_{3}, \mathrm{PaCO}_{2}, \mathrm{PaO}_{2}$, lactate, base deficit and potassium to differentiate the two groups was calculated, but only bicarbonate was found to exhibit a statistically significant difference between the two groups [ p:0.040; Area under the ROC curve: $0.672 ; 64.2 \%$ sensitivity $(95 \%$ CI; $35.1 \%-87.2 \%), 58.4 \%$ specificity $(95 \% \mathrm{CI} ; 44.1 \%-71.8 \%)]$. None of the parameters were valuable in predicting the outcome of CPR at regression analysis.

Conclusions: No statistical value was determined for any blood gas parameter, apart from bicarbonate, in predicting patients with and without ROSC. The value of bicarbonate was also limited.

Keywords: acidosis; bicarbonate; cardiopulmonary arrest; $\mathrm{CPR}$; PaCO2; $\mathrm{PH}$.
Adnan Yamanoğlu

ORCID IDs of the authors: A.Y. 0000-0003-3464-0172 
Amaç: Bu çalı̧̧manın amacı hastane içi kardiak arrest gelişen hastalarda kan gazı parametrelerinin spontan dolaşimin geri dönmesini (SDGD) öngörmedeki değerliliğini belirlemektir.

Yöntem: Bu çalıșmaya, hastane içi kardiyak arrest gelișen ve kardiyopulmoner resüsitasyonun (KPR) ilk 10 dakikası içinde kan gazı analizi elde edilmiş olan erişkin hastalar dahil edildi. Hastalar KPR'nin sonucuna göre SDGD sağlanan ve SDGD sağlanamayan hastalar olmak üzere iki gruba ayrıldı. Kan gazı parametrelerinin bu iki grubu ayırt etme becerisi istataistiksel olarak incelendi. İki grup arasında anlamlı çıkan parametreler için ROC eğrisi çizdirilerek, parametrelerin iki grubu ayırt etme kabiliyeti belirlendi. Kan gazı parametrelerinin CPR'ın sonucunu tahmin etmedeki değerliliğini belirlemek için regresyon analizi yapıldı. Tüm istatistikler \% 95 güven aralığında yapıldı ve $\mathrm{p}<0.05$ istatiştiksel anlamlı kabul edildi.

Bulgular: Bu çalışmaya, 14'ü SDGD sağlanmış, 53'ü SDGD sağlanamamış toplam 67 hasta dâhil edildi. pH, $\mathrm{HCO}_{3}$, $\mathrm{PaCO}_{2}, \mathrm{PaO}_{2}$, laktat, baz defisiti ve potasyumun iki grubu ayırt etme kabiliyeti hesaplanmış ve sadece bikarbonat iki grup arasında istatistiksel olarak anlamlı farklı bulunmuştur [ p: 0.040, ROC eğrisi altında kalan alan: $0.672,64.2 \%$ duyarlılık (95\% CI; 35.1\% - 87.2\%), 58.4\%özgüllük (95\% CI; 44.1\% - 71.8\%)]. Regresyon analizinde parametrelerden hiçbiri CPR'ın sonucunu tahmin etmede anlamlı değerliliğe sahip değildi.

Sonuç: SDGD sağlanan ve SDGD sağlanamayan hastaları tespit etmede bikarbonat dışında herhangi bir kan gazı parametresi istatistiksel olarak anlamlı bulunmadı. Bikarbonatın değerliliği ise sınırlı olarak bulundu.

Anahtar sözcükler: Asidoz, bikarbonat, kardiyopulmoner arrest, parsiyel karbondioksit basinc1, PH.

\section{INTRODUCTION}

The most important factors in return of spontaneous circulation (ROSC) in patients with cardiopulmonary arrest (CPA) are treatment with early identification of shockable rhythms and early provision of advanced life support by initiating chest compression as early as possible ${ }^{1}$. The principal objectives in relation to advanced life support are early determination of the underlying cause of CPA and early intervention in reversible causes. Unfortunately, in this unstable patient group, it is impossible to wait for classical laboratory test results and perform advanced examinations such as computed tomography in conjunction with cardiopulmonary resuscitation (CPR) to determine the underlying cause. Tests and procedures that can only be applied at the bedside and/or that can yield rapid results can be useful in these cases. The use of bedside ultrasound has therefore become very common in these patients ${ }^{2,3}$, while the value of blood gas, one of the laboratory tests capable of yielding the most rapid results, is currently being investigated from several perspectives ${ }^{4,5}$.

Blood gas analysis is known to be capable of providing valuable information concerning etiological factors such as hyperkalemia, diabetic ketoacidosis, and methanol intoxication in critical illnesses. It has also been suggested in recent years that some blood gas parameters can yield valuable information about post-CPR neurological outcomes 4${ }^{6}$. There has been considerable focus on this in recent years, and the value of blood gas analysis in predicting survival in CPA has begun being intensively evaluated, especially in out-of-hospital cardiac arrest (OHCA) ${ }^{6-7}$. Some studies have investigated populations consisting of both OHCA and in-of-hospital cardiac arrest (IHCA) patients ${ }^{4}$. However, it is important to remember that the duration of CPA affects blood gas parameters, in other words, that blood gas parameters are increasingly affected as CPA is prolonged, independently of the arrest etiology ${ }^{8-10}$. The association between blood gas analysis and etiology decreases as CPA is prolonged ${ }^{8,10}$. Blood gas analyses obtained in the early period of CPA may therefore be expected to be more closely associated with cardiac arrest etiology. However, it is difficult to obtain blood gas in the early period of CPA in cases of OHCA, and the times taken to acquire it differs for each patient, because the time elapsed since arrest and time to transportation to hospital differ for patients with OHCA. There is therefore a greater possibility of standardizing time of blood gas acquisition in patients with IHCA. This in turn means that there a greater possibility of evaluating the prognostic value of blood gas analysis with fewer effects caused by other factors. We think that the most important uncertainty in previous studies on this subject concerns blood gas data being 
collected from OHCA patients at times that cannot be standardized. This study was therefore planned to determine the value of blood gas in predicting CPR outcomes in patients with IHCA.

The purpose of this study was to determine the value of blood gas parameters in predicting CPR outcomes in patients with IHCA.

\section{MATERIAL AND METHODS}

\section{Study design and setting}

This retrospective record-based study was performed in the emergency department of a 550 bed-capacity tertiary training and research hospital. The study was approved by the hospital local ethics committee under number 15345988 / 156. The hospital emergency department receives approximately 200,000 patients a year and contains an eight-bed critical care unit providing close monitoring of critical patients and mechanical ventilation support when required. This area contains one three-probe portable ultrasound device, and vascular imaging is frequently performed during arterial blood gas acquisition from patients with CPA. All patients with a high predicted risk of IHCA following presentation to the emergency department are monitored in this area.

\section{Study population}

The target population of this study consisted of all adult non-traumatic patients with IHCA, and with blood gas analyses performed in the first $10 \mathrm{~min}$ of CPR. For this purpose, all patients undergoing CPR in the emergency department were initially included in the study. Of these, individuals aged under 18, with OHCA, with traumatic arrest and for whom blood gas analysis obtained in the first 10 min of CPR was not available were excluded. A flow chart is shown in Figure 1.

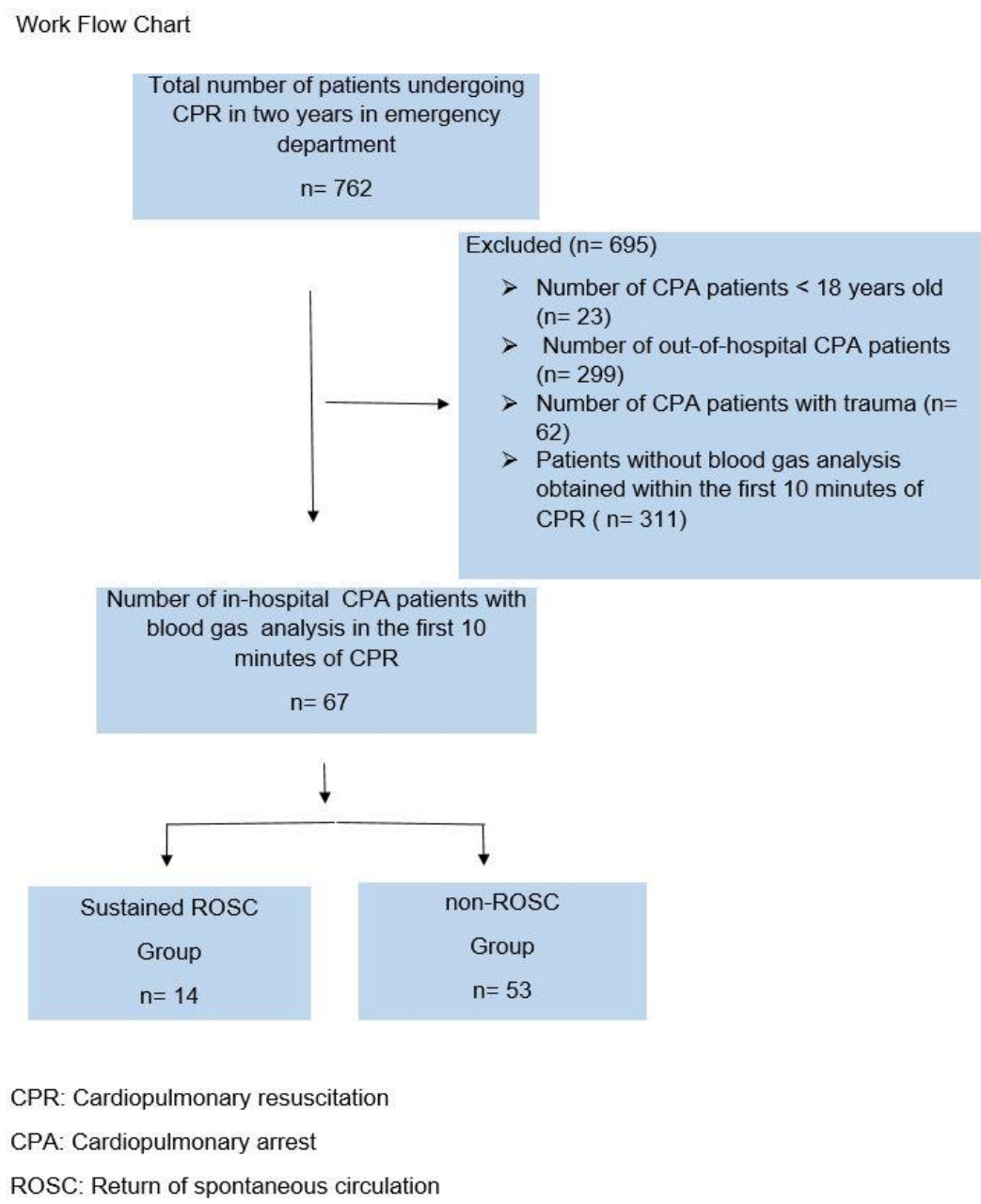

Figure 1: The Work Flow Chart 


\section{Data collection and processing}

The records of all patients undergoing CPR in the emergency department over a two-year period (2016 - 2018) were accessed through a retrospective search of the hospital record system. Time of start of CPR and its duration, and times of performance of all blood gas analyses in these cases were recorded. Patients whose CPA times or time of ROSC/non-ROSC were not clearly written, or cases with more than one CPA in which the time of CPR to which the blood gas obtained corresponded could not be calculated were also excluded (Figure 1). The age, sex, initial rhythm of arrest, clinical diagnoses, CPR duration, and blood gas analysis data of the remaining patients were recorded. Patients were divided into two groups, post-CPR ROSC and non-ROSC. We then compared the two groups' blood gas and other laboratory parameters and investigated the relationship between these parameters and ROSC/non-ROSC status.

\section{Statistical analysis}

Descriptive statistics were expressed as frequency, percentage, mean plus standard deviation, median, minimum and maximum values. Number and percentage values were calculated for categorical variables, and mean, standard deviation, minimum, maximum values and interquartile ranges (IQR) for numerical variables. Histogram curves, kurtosis, and skewness values and the Shapiro-Wilk test were used to determine whether or not data were normally distributed. At independent group comparisons, Student's t test or the Mann Whitney $\mathrm{U}$ test were used to compare continuous variables, depending on whether data were normally distributed. At dependent group comparisons, the Chi-square or Fisher test were used to compare categorical variables. A Receiver Operating Characteristic (ROC) curve was drawn for those parameters that emerged as statistically significant between the groups, and the sensitivity and specificity of the appropriate cut-off values were calculated. The value of blood gas parameters in estimating sustained ROSC and non-ROSC was calculated using logistic regression analysis at a 95\% confidence interval. Previous studies have proposed a second-degree (quadratic) relationship between $\mathrm{PaCO} 2$ and neurological outcome and survival. It has been suggested that the curve of this relationship was in ' $U$ ' shape form, and that excessively high and low values were associated with mortality, while mild-moderately high values were more associated with survival and a good neurological outcome ${ }^{4,10,11}$. On that basis of that hypothesis, curvilinear regression analysis (Quadratic Model) was performed to evaluate the non-linear relationship between $\mathrm{PaCO} 2$ values and survival. All statistical calculations were performed on SPSS 23.0 software. p values $<0.05$ were regarded as significant, and all calculations were performed at a $95 \%$ confidence interval.

\section{RESULTS}

Sixty-seven patients who experienced IHCA underwent blood gas analysis within the first 10 min of resuscitation after endotracheal intubation and met the study inclusion criteria. ROSC was achieved in 14 of these patients, while mortality occurred in 53. Patients' general characteristics are shown in Table 1.

Table 1: Baseline characteristics of the study subjects

\begin{tabular}{|l|c|c|c|c|}
\hline Variables & $\begin{array}{c}\text { All Subjects } \\
(\mathbf{n = 6 7 )}\end{array}$ & $\begin{array}{c}\text { Sustained ROSC } \\
(\mathbf{n = 1 4 )}\end{array}$ & $\begin{array}{c}\text { non-ROSC } \\
(\mathbf{n = 5 3 )}\end{array}$ & p-value \\
\hline Age [years \pm (SD)] & $69 \pm 12$ & $61 \pm 10$ & $71 \pm 13$ & $\mathbf{0 . 0 1 1}$ \\
\hline Female gender[n (\%)] & $24(36 \%)$ & $4(28 \%)$ & $20(38 \%)$ & 0.525 \\
\hline $\begin{array}{l}\text { Initial rhythm } \\
\text { Asystole / PEA }\end{array}$ & $53(79 \%)$ & $8(57 \%)$ & $45(85 \%)$ & \\
\hline \multicolumn{1}{|c|}{ VF / VT } & $14(21 \%)$ & $6(43 \%)$ & $8(15 \%)$ & $\mathbf{0 . 0 2 3}$ \\
\hline $\begin{array}{l}\text { CPR duration } \\
\text { [median(IQR)] }\end{array}$ & $30(30-35)$ & $14(7-21)$ & $30(30-35)$ & $<$ \\
\hline
\end{tabular}

SD: Standard deviation

PEA: Pulseless electrical activity

VF: Ventricular fibrillation

VT: Ventricular tachycardia

IQR: Interquartile range 
Blood gas parameters were compared between the sustained ROSC and non-ROSC patients, and the results are shown in Table 2 . The only statistically significant difference between the sustained ROSC and non-ROSC groups involved bicarbonate values. However, the value of bicarbonate in differentiating surviving and non-surviving patients was limited. The area under the curve (Figure 2) for the ROC curve drawn was 0.672 $(\mathrm{p}=0.049$; Lower Bound $=0.526$; Upper Bound $=$ 0.817 with an Asymptotic 95\% Confidence Interval $[\mathrm{CI}])$. Bicarbonate differentiated the two groups with $64.2 \%$ sensitivity (95\% CI; $35.1 \%$ $87.2 \%$ ), $58.4 \%$ specificity (95\% CI; $44.1 \%$ $71.8 \%$ ), a positive predictive value of $29 \%$ (95\% CI; $19.8 \%-40.3 \%$ ), and a negative predictive value of $86.1 \%$ (95\% CI; $74.7 \%$ - 92.8\%).

Table 2: Comparison of blood gas parameters between the sustained ROSC and non-ROSC groups

\begin{tabular}{|c|c|c|c|c|}
\hline & $\begin{array}{c}\text { All Subjects } \\
(\mathbf{n}=\mathbf{6 7})\end{array}$ & $\begin{array}{c}\text { Sustained ROSC } \\
(\mathbf{n = 1 4})\end{array}$ & $\begin{array}{c}\text { non-ROSC } \\
(\mathbf{n}=\mathbf{5 3})\end{array}$ & p-value \\
\hline $\mathbf{P H}$ & $7.08 \pm 0.19$ & $7.10 \pm 0.14$ & $7.08 \pm 20$ & 0.847 \\
\hline $\begin{array}{c}\mathbf{H C O}_{3} \\
(\mathrm{mEq} / \mathrm{L})\end{array}$ & $17.9 \pm 7.6$ & $21.7 \pm 7.2$ & $16.9 \pm 7.5$ & $\mathbf{0 . 0 4 0}$ \\
\hline $\begin{array}{c}\mathbf{P a C O} \mathbf{2}_{2} \\
(\mathrm{mmHg})\end{array}$ & $62.2 \pm 33.8$ & $72.9 \pm 36.6$ & $59.4 \pm 32.8$ & 0.121 \\
\hline $\begin{array}{c}\mathbf{P a O} \mathbf{O}_{2} \\
(\mathrm{mmHg})\end{array}$ & $56.6 \pm 34.1$ & $56.3 \pm 30.5$ & $56.6 \pm 35.2$ & 0.926 \\
\hline $\begin{array}{c}\mathbf{B E} \\
(\mathrm{mmol} / \mathrm{L})\end{array}$ & $-12 \pm 8.9$ & $-7.9 \pm 7.6$ & $-13.1 \pm 9.05$ & 0.39 \\
\hline $\begin{array}{c}\mathbf{K}^{+} \\
(\mathrm{mmol} / \mathrm{L})\end{array}$ & $4.9 \pm 1.1$ & $4.9 \pm 1.2$ & $5 \pm 1.1$ & 0.579 \\
\hline $\mathbf{L a c t a t e}$ & $11.9 \pm 8.2$ & $13.3 \pm 3.9$ & $11.6 \pm 9$ & 0.069 \\
\hline
\end{tabular}

$\mathrm{K}^{+}$: Potassium

BE: Base excess

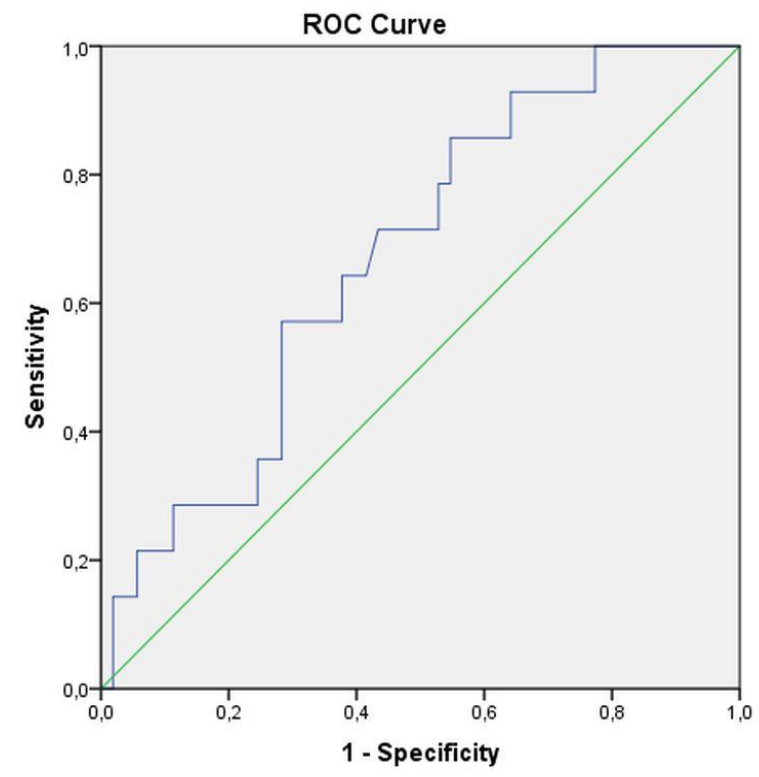

Diagonal segments are produced by ties.

Figure 2: ROC curve demonstrating the ability of bicarbonate to differentiate sustained-ROSC and nonROSC patients

ROC: Receiver Operating Characteristic 
Logistic regression analysis applied to estimate sustained ROSC and non-ROSC via blood gas parameters revealed no effect of blood gas parameters on survival or death (Table 3 ). In other words, increases or decreases in the $\mathrm{pH}, \mathrm{HCO}_{3}$, $\mathrm{PaCO}_{2}, \mathrm{PaO}_{2}$, lactate, base deficit, and potassium parameters evaluated exhibited no linear relationship with CPR outcome. Examination of patients' $\mathrm{PaCO}_{2}$ distributions on a box plot graph revealed that the $\mathrm{PaCO}_{2}$ values of patients with
ROSC were concentrated at higher values than those of non-surviving patients (Figure 3). Therefore, curvilinear regression analysis was then applied to determine whether any secondary relationship was present between $\mathrm{PCO} 2$ and patients' clinical outcomes. This revealed that $\mathrm{PaCO} 2$ possessed no quadratic value ( $\mathrm{p}: 0.399$ ) capable of estimating sustained ROSC or nonROSC.

Table 3: Analysis with multivariate binary logistic regression for sustained ROSC

K: Potassium

\begin{tabular}{|c|c|c|c|c|c|}
\hline Parameters & B & S.E. & Wald & p & Exp (B) \\
\hline HCO3 & 0.183 & 0.432 & 0.180 & 0.671 & 1.201 \\
\hline Lactate & -0.020 & 0.035 & 0.327 & 0.567 & 0.980 \\
\hline PaCO2 & -0.020 & 0.032 & 0.375 & 0.541 & 0.980 \\
\hline PaO2 & -0.002 & 0.009 & 0.042 & 0.839 & 0.998 \\
\hline BE & -0.204 & 0.331 & 0.381 & 0.537 & 0.815 \\
\hline K & 0.005 & 0.276 & 0.000 & 0.987 & 1.005 \\
\hline
\end{tabular}

BE: Base excess

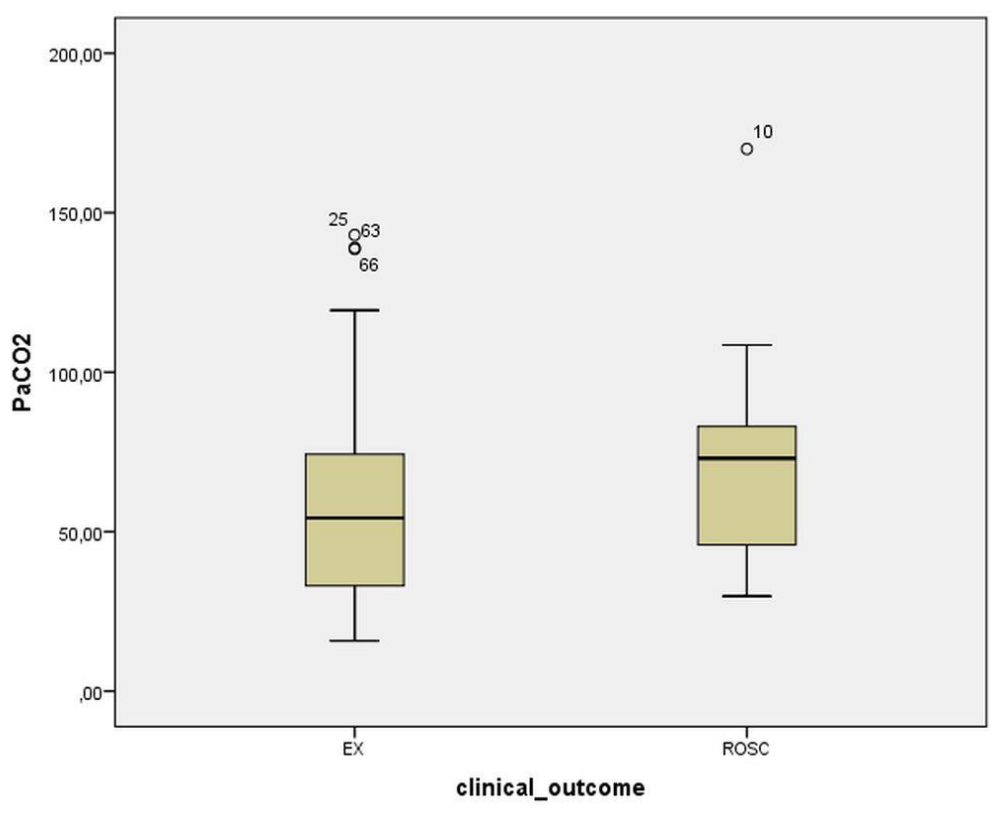

Figure 3: Box plot graphical display of $\mathrm{PCO}_{2}$ distributions among the sustained-ROSC and non-ROSC patients

\section{DISCUSSION}

The establishment of ROSC and subsequent reduction of neurological sequelae are the main aims in CPR. However, few instruments are available to the clinician in the management of
CPR for predicting success in this objective. The most important of these instruments are end-tidal carbon dioxide $\left(\mathrm{ETCO}_{2}\right)$, bedside ultrasound, and blood gas analysis results ${ }^{1}$. Other than these, laboratory and imaging tests are frequently not 
possible in this patient group. The value of blood gas analysis in CPR has been investigated for many years ${ }^{12-14}$. However, there are two significant problems with the reliability of blood gas data obtained in this patient population. The first is that it is difficult to determine whether the blood gas specimen obtained during CPR is arterial or venous without using auxiliary equipment. This can give rise to significant incorrect measurements, particularly in respiratory parameters such as $\mathrm{PaCO}_{2}$ and $\mathrm{PaO}_{2}$. Second, it is not possible to standardize the time of blood gas collection and arrest time, especially in OHCA cases. The present study of the value of blood gas parameters in predicting CPR outcomes therefore investigated IHCA patients, and cases from among that population with blood gas analysis performed in the first $10 \mathrm{~min}$ of CPR were subjected to statistical analysis. In addition, the patient population was included from the critical care zone inside the emergency department, where large vessels (frequently the femoral artery) are generally employed for blood gas collection in arrest patients, and blood gas specimens are frequently obtained with the assistance of ultrasound. The fact that the time of collection of blood gas was standardized and that auxiliary equipment was used during collection via the arterial route represent particular strengths of this study over comparable previous research. In addition, recent studies have unexpectedly suggested that mildly-moderately elevated levels of the blood gas parameter $\mathrm{PaCO}_{2}$ are more closely associated with a better neurological outcome than normal values (35-45 $\mathrm{mmHg}$ ) in post-resuscitation care ${ }^{4,11,15-17}$. The blood gas specimens in these studies were obtained during CPR, the aim being to predict neurological outcome. To the best of our knowledge, the present research is the first to test higher than normal $\mathrm{PaCO}_{2}$ values in predicting CPR outcomes.

With the exception of bicarbonate, no significant difference was determined in any parameter in this study between the ROSC and non-ROSC groups, and even bicarbonate was of low value in differentiating the two groups (Figure 2, area under ROC curve: 0.672). None of the blood gas parameters in this study was therefore useful in predicting the outcome of CPR, or in the decision to prolong CPR or terminate it early. Kim et al. ${ }^{7}$ reported significant differences in $\mathrm{pH}, \mathrm{PaCO}_{2}$ and lactate levels between a sustained ROSC group and a non-ROSC group among patients with OHCA. Shin et al. ${ }^{5}$ also investigated patients with OHCA and found that $\mathrm{PaCO}_{2}$, bicarbonate and lactate differed significantly between the hospital discharge group and the exitus group. Of these results, only the bicarbonate findings in Shin et al. were similar to the present study. The most important reason for this probably involves differences in the study populations. Kim et al. and Shin et al.'s studies both involved OHCA patients. Their patients also had time to be transferred to the hospital. It is therefore likely that blood gas was obtained later from those patients than in the present study. Greater deterioration in all blood parameters may therefore be expected in exitus patients. No linear regression was also determined in the present study between any of the blood gas parameters and mortality or ROSC following CPR (Table 3).

Analysis showed that the $\mathrm{PaCO}_{2}$ values of patients with ROSC concentrated at moderate-high values (Figure 3), while ROSC was not achieved in any patient with normal range $\mathrm{PaCO}_{2}$ values (35-45 $\mathrm{mmHg}$ ), and $72 \%$ of the ROSC patients had $\mathrm{PaCO} 2$ values in the range $57-108 \mathrm{mmHg}$. However, curvilinear regression analysis showed no secondary value of $\mathrm{PCO} 2$ for predicting the result of CPR. Priority has been attached to chest compression rather than to respiration in recent CPR guidelines, and the chest compression/respiration ratio has been increased in favor of the former ${ }^{18,19}$. These recommendations may be expected to result in higher $\mathrm{PaCO}_{2}$ values in association with a decreased respiration count. One previous large-scale study suggested that mild-moderate $\mathrm{PaCO} 2$ values were of quadratic value in predicting sustained $\mathrm{ROSC}^{4}$. In the present study, however, although patients with sustained ROSC had higher PaCO2 values, that elevation was not statistically significant, and our findings were not compatible with this earlier finding. Extensive further clinical studies are now needed to determine the value of $\mathrm{PaCO} 2$ in predicting the outcome of ROSC.

Blood pressure and associated cerebral blood flow are regulated through the mediation of baroreceptors and chemoreceptors. $\mathrm{PaCO} 2$ is one of the most important chemoreceptor regulators of cerebral blood flow, particularly following central nervous system injury ${ }^{20,21}$. Normocapnic values for $\mathrm{PaCO} 2$ have frequently been recommended in CPR and subsequent care objectives 22, 23. However, more recent studies disagree with this recommendation ${ }^{4,16}$. Low $\mathrm{PaCO} 2$ values can reduce cerebral blood flow by causing vasoconstriction, and can therefore exacerbate brain damage ${ }^{20}$. However, an increase in $\mathrm{PaCO} 2$ values has been reported to increase cerebral blood flow by producing vasodilation in cerebral vessels, although if this increase is excessive it may be deleterious by raising intracranial pressure ${ }^{11}$. In addition, it has recently been suggested that mildly- 
moderately elevated $\mathrm{PaCO} 2$ values can regulate cerebral blood flow without raising intracranial pressure, and can improve neurological outcomes ${ }^{4}$, ${ }^{24}$. Almost all these studies have involved postresuscitation patient care, and the present research is the first to test the validity of this hypothesis in predicting ROSC in patients undergoing CPR. Mildly-moderately elevated $\mathrm{PaCO} 2$ values (mean $68 \mathrm{mmHg}$ ) have been linked to a better neurological outcome in post-resuscitation care ${ }^{4}$, while in the present study, higher $\mathrm{PaCO} 2$ values yielded additional potential benefit in achieving ROSC in CPR. However, the present research consists of a small and single-center study, and further prospective studies involving larger patient groups are now needed.

\section{Limitations}

This was a retrospective single-center study. The principal limitation is therefore the relatively low patient number. In addition, as in all retrospective studies, the probability that all blood specimens in this study were obtained via the arterial route is low. This study consisted of cases of IHCA, and for reasons such as gas samples having previously been collected from the same patient and specimens being obtained with the assistance of ultrasound in the emergency department critical care zone, there is a much higher probability of blood gas specimens being arterial than in comparable retrospective OHCA studies. However, confirmation is now needed through extensive, prospectively planned multi-center studies in which all specimens are obtained through the arterial route by means of arterial cannulation.

\section{CONCLUSION}

None of the blood gas parameters in this study emerged as valuable in predicting the outcome of CPR. It is not therefore possible to decide on early termination or continuation of CPR based on blood gas analysis results. No secondary relationship was also observed between PCO2 and CPR for estimating the outcome of CPR. These conclusions now needs to be tested in prospective studies with larger patient populations.

\section{Acknowledgment}

The authors would like to thank Nalan Gokce Celebi Yamanoğlu for the data acquisition and her assistance at the ethical committee stage.

\section{REFERENCES}

1. Robert W. Neumar, Chair, Shuster, Michael ve al., Clifton W. Callaway et 2015 American Heart Association Guidelines Update for
Cardiopulmonary. Circulation. 2015;132 (suppl 2):S315-S367.

2. Jan M. Shoenberger, Kristy Massopust, Sean O. Henderson. The Use of Bedside Ultrasound in Cardiac Arrest. Cal J Emerg Med. 2007 May; 8(2): 47-50.

3. Tomruk O, Erdur B, Cetin G, Ergin A, Avcil M, Kapci M. Assessment of cardiac ultrasonography in predicting outcome in adult cardiac arrest. J Int Med Res. 2012;40(2):804809. doi:10.1177/147323001204000247

4. Hope Kilgannon J, Hunter BR, Puskarich MA, et al. Partial pressure of arterial carbon dioxide after resuscitation from cardiac arrest and neurological outcome: A prospective multicenter protocol-directed cohort study. Resuscitation. $\quad 2019 ; 135: 212-220$. doi:10.1016/j.resuscitation.2018.11.015

5. Shin J, Lim YS, Kim K, et al. Initial blood pH during cardiopulmonary resuscitation in out-ofhospital cardiac arrest patients: a multicenter observational registry-based study. Crit Care. 2017;21(1):322. Published 2017 Dec 21. doi:10.1186/s13054-017-1893-9

6. Wang HE, Prince DK, Drennan IR, et al. Postresuscitation arterial oxygen and carbon dioxide and outcomes after out-of-hospital cardiac arrest. Resuscitation. 2017;120:113-118. doi:10.1016/j.resuscitation.2017.08.244

7. Kim YJ, Lee YJ, Ryoo SM, et al. Role of blood gas analysis during cardiopulmonary resuscitation in out-of-hospital cardiac arrest patients [published correction appears in Medicine (Baltimore). 2016 Aug 26;95(34):e450a]. Medicine (Baltimore). 2016;95(25):e3960. doi:10.1097/MD.0000000000003960

8. Gando S, Tedo I, Kubota M. A comparison of serum ionized calcium in arterial and mixed venous blood during CPR. Ann Emerg Med. 1990;19(8):850-856. doi:10.1016/s01960644(05)81556-2

9. Kim MJ, Jeung KW, Lee BK, et al. Femoral venous oxygen saturation obtained during CPR predicts successful resuscitation in a pig model. Am J Emerg Med. 2015;33(7):941-945. doi:10.1016/j.ajem.2015.04.004

10. Strnad M, Lešnik D, Križmarić M. Arterial blood gas changes during cardiac arrest and cardiopulmonary resuscitation combined with passive oxygenation/ventilation: a METI HPS study. J Int Med Res. 2018;46(11):4605-4616. doi:10.1177/0300060518786916

11. Roberts BW, Kilgannon JH, Chansky ME, Mittal N, Wooden J, Trzeciak S. Association between post resuscitation partial pressure of arterial carbon dioxide and neurological 
outcome in patients with post-cardiac arrest syndrome. Circulation. $\quad 2013 ; 127(21)$ :21072113. doi:10.1161/CIRCULATIONAHA.112.00016 8

12. Çalbay A, Çakır Z, Bayramoğlu A. Prognostic value of blood gas parameters and end-tidal carbon dioxide values in out-of-hospital cardiopulmonary arrest patients. Turk $\mathrm{J}$ Med Sci. 2019;49(5):1298-1302. Published 2019 Oct 24. doi:10.3906/sag-1812-156

13. Kilgannon JH, Jones AE, Shapiro NI, et al. Association between arterial hyperoxia following resuscitation from cardiac arrest and in-hospital mortality. JAMA. 2010;303(21):2165-2171. doi:10.1001/jama.2010.707

14. Prause G, Ratzenhofer-Comenda B, SmolleJüttner $\mathrm{F}$,et al. Comparison of lactate or $\mathrm{BE}$ during out-of-hospital cardiac arrest to determine metabolic acidosis. Resuscitation. 2001 Dec;51(3):297-300.

15. Roberts BW, Kilgannon JH, Chansky ME, Trzeciak S. Association between initial prescribed minute ventilation and postresuscitation partial pressure of arterial carbon dioxide in patients with post-cardiac arrest syndrome. Ann Intensive Care. 2014;4(1):9. Published 2014 Mar 7. doi:10.1186/2110-58204-9

16. Eastwood GM, Schneider AG, Suzuki S, Peck L, Young H, Tanaka A, et al. Targeted therapeutic mild hypercapnia after cardiac arrest: A phase II multi-centre randomised controlled trial (the CCC trial). Resuscitation. 2016;104:83-90.

17. Helmerhorst HJ, Roos-Blom MJ, van Westerloo DJ, Abu-Hanna A, de Keizer NF, de Jonge E. Associations of arterial carbon dioxide and arterial oxygen concentrations with hospital mortality after resuscitation from cardiac arrest. Crit Care. 2015;19:348.

18. Hazinski MF, Nolan JP, Billi JE, et al. Part 1: Executive summary: 2010 International
Consensus on Cardiopulmonary Resuscitation and Emergency Cardiovascular Care Science With Treatment Recommendations. Circulation. 2010;122(16 Suppl 2):S250-S275. doi:10.1161/CIRCULATIONAHA.110.97089 7

19. Neumar RW, Shuster M, Callaway CW, et al. Part 1: Executive Summary: 2015 American Heart Association Guidelines Update for Cardiopulmonary Resuscitation and Emergency Cardiovascular Care. Circulation. 2015;132(18 Suppl 2):S315-S367. doi:10.1161/CIR.0000000000000252

20. Yundt KD, Diringer MN. The use of hyperventilation and its impact on cerebral ischemia in the treatment of traumatic brain injury. Crit Care Clin. 1997;13:163-84.

21. Roberts BW, Karagiannis P, Coletta M, Kilgannon JH, Chansky ME, Trzeciak S. Effects of $\mathrm{PaCO} 2$ derangements on clinical outcomes after cerebral injury: A systematic review. Resuscitation. 2015 Jun;91:32-41. doi: 10.1016/j.resuscitation.2015.03.015. Epub 2015.

22. Callaway CW, Donnino M, Fink E, Geocadin RG, Golan E, Kern KB, et al. Part 8: Postcardiac arrest care: 2015 American Heart Association Guidelines Update for Cardiopulmonary Resuscitation and Emergency Cardiovascular Care. Circulation. 2015;132:S465-S82.

23. Nolan JP, Hazinski MF, Aickin R, et al. Part 1: Executive summary: 2015 International Consensus on Cardiopulmonary Resuscitation and Emergency Cardiovascular Care Science with

Treatment Recommendations. Resuscitation. 2015;95:e1e31. doi:10.1016/j.resuscitation.2015.07.039

24. Eastwood GM, Tanaka A, Bellomo R. Cerebral oxygenation in mechanically ventilated early cardiac arrest survivors: The impact of hypercapnia. Resuscitation. 2016;102:11-6. 